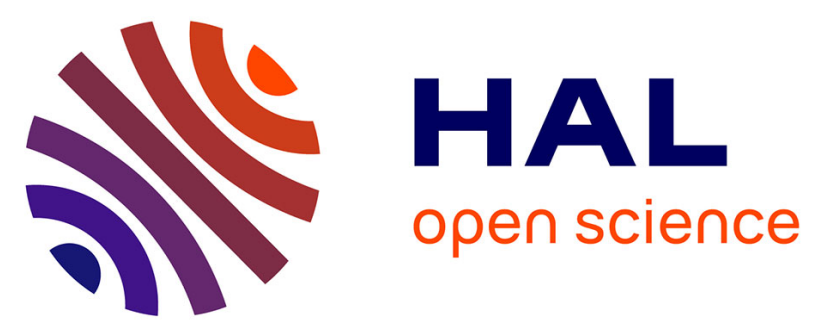

\title{
Can a governance structure foster cluster ambidexterity through knowledge management? An empirical study of two French SME clusters
}

Rachel Bocquet, Caroline Danièle Mothe

\section{- To cite this version:}

Rachel Bocquet, Caroline Danièle Mothe. Can a governance structure foster cluster ambidexterity through knowledge management? An empirical study of two French SME clusters. Knowledge Management Research and Practice, 2015, 13 (3), pp.329-343. 10.1057/kmrp.2013.53 . hal-01132584

\section{HAL Id: hal-01132584 \\ https://hal.univ-grenoble-alpes.fr/hal-01132584}

Submitted on 3 Oct 2017

HAL is a multi-disciplinary open access archive for the deposit and dissemination of scientific research documents, whether they are published or not. The documents may come from teaching and research institutions in France or abroad, or from public or private research centers.
L'archive ouverte pluridisciplinaire $\mathbf{H A L}$, est destinée au dépôt et à la diffusion de documents scientifiques de niveau recherche, publiés ou non, émanant des établissements d'enseignement et de recherche français ou étrangers, des laboratoires publics ou privés. 


\section{Can a governance structure foster cluster ambidexterity through knowledge management? An empirical study of two French SME clusters}

\author{
Rachel Bocquet ${ }^{1}$ and \\ Caroline Mothe ${ }^{1}$ \\ ${ }^{1}$ IREGE, University of Savoie, France
}

Correspondence: Caroline Mothe, IREGE, University of Savoie, 4 chemin de Bellevue, Annecy le Vieux, BP 80439, 74944, France. Tel: $0033(0) 45002455$

\begin{abstract}
To identify how a governance structure leads to ambidexterity at the cluster level, in terms of knowledge management, this study draws on the knowledge -based view of clusters and on ambidexterity literature, thereby exploring an 'intermediated' cluster model of ambidexterity. Our aim is to explore the governance structure's role and priorities in terms of knowledge management, as well as the underlying operational actions and programmes implemented to achieve cluster ambidexterity. Qualitative research, based on interviews with members of two French clusters, reveals that their governance structure is a crucial intermediary organisation that supports cluster ambidexterity. The results emphasise the role of governance structures for two types of ambidexterity in small and medium-sized enterprise (SME) clusters: First, SMEs may specialise in exploitative or exploratory knowledge, and the governance structure provides the missing knowledge (intermediated specialised model). Second, cluster governance may help each firm become ambidextrous (intermediated dual model). This study outlines the specificities of the two models and their contingency factors, which offer interesting implications, especially for policymakers devoted to innovation and clusters.
\end{abstract}

Keywords: ambidexterity; knowledge; governance structure; cluster; innovation

\section{Introduction}

The knowledge-based view suggests that a primary firm function is to create, integrate and apply knowledge (Nonaka, 1994; Nonaka \& Takeuchi, 1995; Grant, 1996; Nonaka et al, 2006; Bierly \& Daly, 2007). Related literature further suggests that sources of knowledge consist of internal and external aspects, such that firms might balance their internal and external learning (Zack, 2003). In such scenarios, firms must seek complementarities between their activities designed to create internal knowledge and those aimed at the assimilation of external knowledge (Zahra \& George, 2002; Kraaijenbrink \& Wijnhoven, 2008; Camison \& Villar-Lopez, 2012). Innovation research also offers some consensus that firms should develop their capacity to explore new technological paths, even as they continue to exploit existing competences (e.g., March, 1991; Tushman \& O’Reilly, 1996; O'Reilly \& Tushman, 2004). An appropriate balance can help firms gain a competitive advantage in mature markets, in which costs, efficiency and incremental innovations are more 
critical, as well as innovate in emerging markets, in which experimentation and flexibility are required (Tushman \& O'Reilly, 1996). This ability to pursue the two contradictory objectives simultaneously is called 'ambidexterity'.

Although some studies investigate inter-firm knowledge flows at a macro level, such as in innovation networks (Sammarra \& Biggiero, 2008), few investigations pertain to ambidexterity in clusters (Ferrary, 2011). With this study, we compare knowledge management strategies and ambidexterity beyond the organisational level, namely, at interorganisational and cluster levels. Ambidexterity in clusters differs from ambidexterity in organisations because it may take various forms. The cluster may be ambidextrous because it consists of ambidextrous firms (intermediated dual model), or it may comprise some firms that specialise in exploration and others that specialise in exploitation, which cooperate to form the ambidextrous cluster (intermediated specialised model). Between these two ends of the spectrum, multiple intermediate forms exist too.

The potential 'intermediary' role of governance structures has also been neglected, although they might help firms benefit from external knowledge flows, for exploration and/ or exploitation, and foster ambidexterity in a cluster. The knowledge-based view of clusters (KBVC; Malmberg \& Maskell, 1997, 2002; Maskell, 2001; Bathelt et al, 2004; Bahlmann \& Huysman, 2008) suggests the need to identify the role of cluster governance with respect to knowledge, especially for clusters composed of small and medium-sized enterprises (SMEs). Some prior research asserts that ambidexterity benefits small firms (Lubatkin et al, 2006; Bierly \& Daly, 2007; Lee et al, 2010), whereas other studies highlight the difficulties of achieving ambidexterity for SMEs because of their limited resources (March, 1991; Lin et al, 2007). Small firms may procure ambidexterity externally, through inter-organisational ties (Rothaermel \& Deeds, 2004), in which case SMEs in search of ambidexterity might compensate for their lack of internal resources by developing relations with other organisations (e.g., research labs, startups, competitors, suppliers, clients). Such network ambidexterity then should mark SME clusters, which aim to benefit from firm heterogeneity and labour divisions within the cluster (Ferrary, 2011) to boost collective innovation.

To bridge these research fields, we analyse the role of cluster governance for member firms, mostly SMEs, in terms of cluster ambidexterity. Drawing on the KBVC, ambidexterity and intermediary literature, we explore an intermediated cluster model of ambidexterity that features the influence of the governance structure. We then present our empirical qualitative research methodology, which focuses on two SME clusters. Finally, we discuss the main theoretical and managerial implications of our findings, especially for policymakers and cluster managers, and propose some avenues for further research.

\section{Literature review}

In reviewing existing literature, we note two key research gaps, which this study seeks to address. First, the KBVC emphasises that geographical proximity may not be sufficient to encourage knowledge spillovers, which 'do not flow freely in the atmosphere' (Antonelli, 2006, p. 253). Instead, at the cluster level, firm interactions need to be organised carefully to encourage them to engage in knowledge processes. Theoretical and empirical studies of knowledge management remain scarce though. Second, most ambidexterity studies pertain to the organisational level. We pursue a less developed research line (e.g., Ferrary, 2011) that addresses how to reach ambidexterity at a collective (i.e., cluster) level, to ensure not just individual but also collective performance. This question of whether a cluster may become ambidextrous is gaining interest as (innovation) clusters increase in significance and prominence (Ferrary, 2011). With this research, we analyse precisely how a cluster governance structure might facilitate knowledge management to encourage cluster ambidexterity. Such ambidexterity might take different forms, depending on the governance structure's role and priorities in terms of knowledge management.

\section{Types of innovation clusters and the role of governance structures}

Various perspectives and theoretical approaches seek to explain clusters. Early studies derived from Marshall's (1920) initial reflections focused on local spillovers (pecuniary and knowledge externalities), until Porter's (1998) theory of cluster growth shifted the emphasis to competition at the cluster level. More recently, the KBVC (Malmberg \& Maskell, 1997, 2002; Maskell, 2001; Bathelt et al, 2004; Bahlmann \& Huysman, 2008) has emerged to highlight the role of knowledge creation, in which clusters exist 'to create a competitive advantage for the collective as well as individual firms by enhancing individual firms' knowledge creation efforts' (Arikan, 2009, p. 3). Although cluster theory originally was developed in support of the view that concentration causes firms' innovation and economic growth, the KBVC instead predicts that concentration and proximity alone cannot explain such performance (Boschma, 2005; Torre \& Rallet, 2005; Ponds et al, 2007). Thus, cluster effects do not necessarily arise because common knowledge becomes available to cluster members, whether or not it is consciously communicated (Marshall, 1920). In contrast with Marshallian or Porterian views, the KBVC asserts that firms are not the only important actors and that local synergy can and should be enhanced through the creation of local agents d'animation or cross-firm organisers (Maskell, 2001). In contrast with theories of 'network governance' (Jones et al, 1997), the governance of clusters is not always dispersed across parties. Rather, cluster governance, defined as 'the intended, collective actions of cluster players in view of upgrading a cluster' (Gilsing, 2000, p. 7), takes a more centralised, formal character through a dedicated structure in charge of its orientation and its animation.

Such a cluster governance structure may be as important as geographical proximity for knowledge diffusion and creation (Alberti, 2001). However, despite the importance of 
'governing knowledge, both in organizations and clusters' (Bahlmann \& Huysman, 2008, p. 315), we still know little about the role of governance structures in clusters. Cluster literature rarely addresses their involvement in knowledge management or in how the creation and diffusion of different types of knowledge can lead to cluster ambidexterity.

\section{The roles of intermediaries in clusters}

Intermediaries play an important role in national and regional innovation systems, especially for innovation policy and processes (Howells, 2006). In linking organisations within an innovation system, intermediaries focus on technology transfer, commercialisation of ideas and funding (Inkinen \& Suorsa, 2010). These organisations aim to support innovation creation, dissemination and collaboration (Inkinen \& Suorsa, 2010). In characterising innovation mediation research, Howells (2006) distinguishes two emergent research fields: investigations focused on 'intermediaries as organisations' and studies that view 'intermediation as a process'. Several studies also approach innovation mediation through the particular functions of intermediaries (Howells, 2006).

Our study falls within this tradition of innovation research that focuses on organisations rather than processes. Despite growing attention to the essential role of intermediaries in clusters, general intermediary literature has relatively little to say about 'superstructure organizations' (Lynn et al, 1996), including technical assistance centres, university outreach programmes, vocational training centres and local research institutes, all of which provide a host of collective support services to their members. Studying the creation and categorisation of knowledge in automotive component SMEs in India, Pillania (2008, p. 1460) concludes that 'government and industry associations play an important role in creating the eco-system for new knowledge creation among SMEs' but without specifying that role. Lee et al (2010) emphasise the role of specific intermediaries (e.g., associations) that can support and encourage open innovation strategies at the exploration and exploitation stages. Spithoven et al (2011) argue that third parties are necessary to build absorptive capacity and organise inbound open innovation. They highlight the support and assistance of collective technical institutions to enable firms to scan the market for technologies, develop their abilities to absorb the acquired technology and knowledge and perform complementary research and development (R\&D) activities.

In contrast, literature on knowledge exchange intermediaries (KEI) is more abundant (e.g., Hine et al, 2010). Such intermediaries are service organisations, usually created with government support and funding to encourage the transfer of knowledge. In addition, KEIs usually offer two types of programmes: technology push, such that they work with researchers to 'push' for the culmination of research projects and programmes in the market, or market pull, where the KEIs work with an industry partner to identify early-stage research being developed by a research institute and 'pull' this technology into the firm. The design of intermediary programmes should match the service type they offer (Hine et al, 2010): Market-pull programmes require market-pull designs in close collaboration with industry, whereas technology programmes can be problem-solving innovations for which demand is latent. Although the KEI's task is to integrate the knowledge bases of the parties it intermediates, such that it makes itself redundant in the individual exchange process, it continually enhances its value to the innovation system through its constantly evolving knowledge set. The best means by which a KEI can achieve an integrative role in the knowledge exchange process is by developing programmes that meet the needs of the different markets to which it caters. Therefore, KEIs must be as innovative as the knowledge generators and the knowledge users with which they work. Publicly funded organisations based on single programmes will find it difficult to survive in such a setting. At the intersection of these two research streams, Waxell (2009) emphasises the key role of complementary actors on network-level cooperation and relations within a cluster. Different types of organisations stimulate such relations and act as intermediaries among actors in a region, with the purpose of stimulating collaboration, interaction and knowledge spillovers in a region or a specific industry. These formal institutions for collaboration (IFC) are 'complementary agents' (Waxell, 2009, p. 1612); they are mainly local or regional industry or trade organisations, with different types of cluster member organisations.

In line with these works, which acknowledge the importance and key role of intermediaries in SMEs' clusters, we seek to deepen comprehension of the knowledge programmes developed by KEIs (Hine et al, 2010) or IFCs (Waxell, 2009) - with a particular focus on formal cluster governance structures - for cluster ambidexterity. We consider governance structures a specific type of intermediary organisation, in charge of cluster governance. In contrast with industrial districts or clusters à la Porter, the presence of a formal governance structure, which is a superstructure organisation (Lynn et al, 1996), is a prerequisite for the very existence of French clusters (or 'competitiveness poles'). Inkinen \& Suorsa (2010, p. 185) describe governance structures as local and regional intermediaries that concentrate on the promotion of networking between actors. We also consider Inkinen \& Suorsa's (2010, p. 185) recommendation that, 'besides funding, there is a need to further develop other support measures such as project development and knowledge dissemination'. To explicate this role, we account for local and geographical contexts. Such an effort is particularly challenging in France, where significant gaps remain between private and public R\&D investments and firms' innovation performance (Howells, 2006). Thus, the governance structure could serve as a bridge, enhancing cluster ambidexterity through specific knowledge management.

\section{Ambidexterity and its role in SME clusters}

March's (1991) pioneering article helped spread the conceptual distinction of exploration from exploitation to 
various fields. Exploration and exploitation involve different degrees and types of learning (Gupta et al, 2006), and finding the appropriate balance is both complicated and essential for organisational survival (March, 1991). Some studies suggest balancing exploration and exploitation with boundary-spanning activities across organisations (Ferrary, 2011). Using external knowledge from other cluster members, firms could limit the necessary trade-offs between knowledge exploitation and exploration activities (Oshri et al, 2005).

In a network, ambidexterity may take two forms (Kauppila, 2007). First, in line with Tushman \& O'Reilly's (1996) assumption regarding the separation of exploration and exploitation activities, firms might specialise in one or the other. Cluster ambidexterity then occurs through the development of inter-organisational relationships. Because actors cannot possess simultaneous exploration and exploitation competencies, firms make the network ambidextrous by 'taking on different burdens with respect to exploitation and exploration' (Kauppila, 2007, p. 20). This model implies specialisation. Second, reflecting Gibson and Birkinshaw's (2004) idea that individuals can embody ambidexterity, each cluster firm may exhibit organisational ambidexterity, with the objective of internalising complementary knowledge. We refer to this model as a 'dual' form, in the sense that it reflects the capacity of the firm to associate two apparently 'opposite' activities, and as used by Duncan (1976), who introduced the notion of organisational ambidexterity. In this model, 'the companies make each other ambidextrous by using the network' (Kauppila, 2007). The question of which model is more efficient remains unsolved. Kauppila (2007) considers the dual model more appropriate and manageable in practice, but Ferrary (2011) shows that the specialisation model is also efficient with a 20-year comparison of Lucent Technologies and Cisco Systems. Cisco Systems' presence in the ambidextrous, high-tech Silicon Valley cluster, as well as its close ties to venture capital firms and start-ups, explain the success of its growth strategy.

In line with the previously mentioned studies on the role of intermediaries in knowledge management in clusters (Kauppila, 2007; Bocquet \& Mothe, 2010; Spithoven et al, 2011), we propose an 'intermediated' cluster model of ambidexterity, in which cluster governance structures provide the necessary skills and processing abilities to support the acquisition, assimilation (potential absorptive capacity), transformation and exploitation (realised absorptive capacity) of knowledge (Zahra \& George, 2002). In turn, they help specialised firms collaborate or enable each firm to become ambidextrous. By identifying the different means by which a governance structure may lead to cluster ambidexterity, we contribute to extant literature on ambidexterity, intermediaries and knowledge (Datta, 2011). We thus explore how the cluster governance structure, through specific programmes (Hine et al, 2010) especially those focused on knowledge management (Zahra \& Georges, 2002) - can develop cluster ambidexterity by bridging firms' knowledge gaps.

\section{Methodology and cases}

In 2005, the French government set a new public policy for regional planning and development, based on the creation of 'competitiveness poles'. These poles would group firms, research labs and education institutions within a specific geographic area and impose a collaborative approach to create synergies in innovative projects, oriented towards one or more markets. This definition emphasises the important role of geographical proximity, in that it offers easier access to information, helps foster knowledge exchanges and facilitates innovation diffusion.

As indicated in Appendix A, the cluster governance structure is composed of two (strategic and operational) levels. At the strategic level, the executive board defines the strategic priorities, rules and roles for the cluster governance. At the operational level, a dedicated team or committee transforms and implements these rules into specific actions and programmes. Although most literature on cluster governance describes it as an informal process, France's competiveness poles instead are required to have formal structures that take responsibility for their governance (Bocquet \& Mothe, 2010).

We analysed two French competitiveness poles (hereafter, clusters) that consist mainly of SMEs located in the French Rhône-Alpes region. We selected the Arve-Industries and Imaginove clusters because they not only share common characteristics but also differ significantly in their backgrounds (long tradition $v s$ short history), culture and leadership profiles (secrecy and tradition $v s$ openness and modernity), type of industry (metal-working $v s$ cultural), position in the value chain (subcontractors vs distributors/producers) and competitive dynamics among member firms (high competition among similar actors $v s$ low competition among heterogeneous actors).

For these two case studies, we collected both primary and secondary data with the staff of the two governance structures (see Appendix A). We conducted 29 interviews between January and March 2009, as well as 2 in June 2011 and 2 in September 2012 (33 interviews total). Among the Arve-Industries cluster, we interviewed all 7 members of the executive committee, 7 members of the Executive Board and Administration Council and 5 project managers (19 interviews). For Imaginove, we conducted 10 interviews with the director and all Board members. In June 2011, we added 2 more interviews with the two governance structures' directors, to collect additional performance indicators at the cluster level. We also repeated these two interviews 1 year later (September 2012) to evaluate any evolution or changes. The semi-structured, face-to-face interviews lasted $2 \mathrm{~h}$ on average (see the interview guide in Appendix B). The structure of the interviews reflected our research goals, namely, to assess whether knowledge management and cluster ambidexterity were recognised objectives of the governance structure, as well as to understand how the governance structure might foster cluster ambidexterity through the development of exploration and exploitation knowledge, and which programmes and actions it thus implements. 
All interview questions related to knowledge management, exploration and exploitation came from prior empirical and theoretical literature (e.g., Nonaka, 1994; Lazaric et al, 2008; Martin-de-Castro et al, 2008). The interviews were transcribed, validated by the respondents and coded according to the main themes that emerged. The key themes that we derived included mechanisms of cluster emergence, members' characteristics and performance, governance structures (strategic and operational), roles and priorities (especially in terms of knowledge management and ambidexterity), programmes (projects/ actions) implemented to support knowledge management processes throughout the different phases, types of knowledge produced through these programmes (exploitation/ exploration) and performance.

Initially, we relied on open coding to identify the categories and major data themes, which we added to existing themes stemming from prior literature. Then we analysed the data sequentially, using a combination of Miles \& Huberman's (1984) coding procedures. (An example of the coding grid is attached in Appendix C.) To check for reliability, we dual-coded 10 (about one-third of the total) randomly selected interviews (Miles \& Huberman, 1994) and tested for inter-coder reliability by determining whether both researchers assigned the majority of verbatim comments to the same themes. The inter-coder reliability rate, calculated according to Miles \& Huberman's (1994) method (number of agreements/[total number of agreements+disagreements]), reached $89 \%$, which is satisfactory. In addition, to resolve any differences of opinion, we asked a third coder (a doctoral student familiar with the two studied cases and prior literature) to analyse the $11 \%$ of disagreements and choose the appropriate code.

Next, we identified repetitive patterns in the interviews by comparing the verbatim comments contained in each theme, which enabled us to shed light on the main differences between the two clusters and governance structures. We also gathered secondary data to support data triangulation, including press accounts, government and cluster websites, articles and scientific communications at conferences. These data confirmed any recurring patterns and identified other facets, elements and quantitative figures that might support (or conflict with) the information gleaned from our interviews (see Appendix C).

Because our methodological approach includes interviews with various actors who engage in governancerelated efforts, we have limited the potential bias that is inherent to case studies, arising from the use of respondents' own perceptions and representations. We can also determine whether different governance actors (public and private organisations and institutions) shared a common vision in terms of knowledge management and ambidexterity.

\section{Arve-Industries}

Arve-Industries included, as of 25 March 2012, 272 member companies (93\% SMEs), 28 public laboratories,
30 private laboratories, 12 technical training centres and 25 institutional and territorial actors (including 10 municipalities). The companies are located in the Technic Valley industrial district, which hosts 800 SMEs involved in metal-working subcontracting. These firms entail multiple businesses and skills, such as cutting, precision mechanics, assembly, materials surface treatment and precision grinding.

The cluster was established at the initiative of politicians in Haute-Savoie to foster innovation dynamics for the Technic Valley. Small firms previously had been focused on continuous improvements to their existing products, services and organisational processes. However, environmental changes (e.g., increased competition from Asia, tighter contractor requirements) required them to engage in more exploration to find new sources of competitive advantage. The established objective of the cluster governance therefore was to help subcontracting firms develop new knowledge and competencies to design more complex products, including mechatronics products that integrated mechanics, electronics and computing. To increase the firms' value creation, two 'core business' programmes (cutting, machining and mechatronics) and six 'quality and performance' programmes (tolerancing for conception - which seeks to determine acceptable tolerances around nominal values, industrial performance, open innovation, human resources, economic environment and international performance) were implemented.

The cluster's priority is to guide traditional subcontractors [i.e. subcontractors of economy and of specialisation] towards excellence. To this effect they must be able to absorb new knowledge. Since 2006, all of our programs contribute to this objective. (cluster governance structure member in charge of communication, February 2009)

The cluster adopted a pre-existing territorial logic (industrial district), characterised by strong local roots, a legacy of private industry and initiatives and a culture of secrecy. Everyone knew one another, but the different communities of practice did not mix. In each community, tacit knowledge spread through face-to-face contacts. The industrial district succeeded in pooling resources around a local platform, but it did not bridge the different communities of practices. Subcontracting firms remained highly specialised and interested in protecting their specific technical know-how. Few of them engaged in exploration or R\&D activities. As indicated in Appendix D, between 2009 and 2011 only an average of $24 \%$ of $R \& D$ projects established an SME as a project leader. In 2011, SMEs participated in only $36 \%$ of R\&D projects. These projects were mainly 'engines' for larger firms that already were better able to perceive opportunities and benefit from external knowledge. For them, the cluster played a screening role and provided new connections:

When dealing with cutting or machining, it is not easy to convince [exploitative] firms of the need to innovate. However, for programs covering business intelligence and 
mechatronics, it means something to some [exploratory] firms, that we call the 'engines'. (member of the governance structure in charge of technological watch and knowledge intelligence, Technical centre, March 2009)

Several governance structures served as orchestrators, especially the Technical Centre for Cutting and Mechatronics (CTDEC), the regional innovation centre (Thésame) and the scientific laboratories of the University of Savoie. Our respondents insisted on the role of governance for screening and identifying external scientific and technological knowledge. Governance actors appeared essential for gaining new knowledge and exploring the future of mechatronics. In 2007, less than 50\% of cluster members were involved in at least one action associated with a programme implemented by the governance structure, which indicated the low motivation of most SME members. However, $78 \%$ of the companies had become involved in 2011, and that rate grew in 2012. Yet despite this increase, the data continued to indicate differences between the engines and the other members. The engines participated in exploration-oriented programmes, whereas the small firms mostly waited for the exploitation phase, during which new knowledge would be disseminated throughout the cluster:

SMEs are still reluctant to participate in programs that involve a fundamental change in the way to do business because they remain focused on short-term requirements. (member of the governance structure, June 2011)

These small firms could benefit from the R\&D projects' results by participating in collective actions (e.g., seminars for top managers, 12-14 h meetings organised by the cluster) or individual actions (during which governance structure members or external consultants directly spread new technological knowledge to firms). The roles of CTDEC, Thésame and the university were crucial to the exploitation phase, in that they took charge of converting technological knowledge into new processes and products, then disseminating this knowledge for the benefit of the largest number of cluster members. This situation explains, for example, the success of the first cutting/machine programme, which helped more than 50 companies implement the Pack Cut Optimiser , a tool that provided new technological knowledge in the field of cutting tool usage and resulted in the optimisation of cutting conditions nearly immediately, such that it reduced production costs by $20-30 \%$. Thus,

\footnotetext{
We help companies to move towards another type of subcontracting which incorporates research and innovation.... We engage in applied research on behalf of companies, and help them to implement research results. (member of the governance structure and program pilot, University VicePresident, January 2009)
}

The current governance processes in Arve-Industries include more formalised methods that aim for better targeting of cluster members and a broader dissemination of new knowledge:
Up to now, our force lies in the sharing of tacit information which is well suited to the spirit of SMEs. But we are entering into the era of formalisation, which is absolutely necessary to enhance knowledge. The launch of the new Program and Process Direction is a priority. (member of the governance structure, Thésame, June 2011)

In terms of cluster governance and ambidexterity (see Table 1), this case illustrates that the governance programmes and actions supported a particular form of ambidexterity, in which most firms remain specialised in one activity, namely, exploitation.

$52 \%$ of our member firms work for the high precision turning industry and focus on exploiting their existing knowledge and competencies. Another 30\%, mostly sub-contractors and very small firms, also basically exploit. So that less than $20 \%$ of the firms, those that are in the fast-evolving mechatronics industry, manage to combine exploration and exploitation in terms of knowledge. They are the engines of ArveIndustries. (managing director of the governance structure, September 2012)

First, the governance structure helped the engines become or stay ambidextrous through R\&D collaborations with research institutions (thus providing them the necessary programmes to create new exploration knowledge). Second, for SMEs oriented towards exploitation, the governance provided some new technologies and tools that stemmed from inter-organisational R\&D cooperation, and then helped them absorb exploration knowledge through direct support and assistance within the firms. The underlying idea was not to make these firms ambidextrous but to reach ambidexterity at the cluster level by involving various specialised SMEs in concrete programmes that reflected the cluster's business units (e.g., tolerancing, industrial performance, human resources and international performance; see Arve-Industries, 2012).

In fact, the governance is very active in helping the small firms with few resources to integrate the exploratory knowledge and competencies developed by others, for instance in $\mathrm{R} \& \mathrm{D}$ cooperation projects. We go directly in the firms' factories to implement, for instance, machines for tolerancing - that increase productivity. We here have transferred the results of our first UIF [i.e. the Unique Interministery Fund, which finances collaborative R\&D projects within French clusters] project to many small firms. (managing director of the governance structure, September 2012)

The cluster's governance actions thus acted as a substitute for cluster inter-relations, which were difficult for Arve-Industries to develop because of its historical characteristics, and they provided firms with necessary complementary knowledge. Thus, the cluster showed firms the benefits of access to external knowledge, through actions intended to enhance their productivity and industrial performance, which should lead them to achieve cluster ambidexterity through inter-organisational relationships (Kauppila, 2007). The governance structure had a key role in making the 
Table 1 Main findings

\begin{tabular}{|c|c|c|}
\hline & Arve-Industries & Imaginove \\
\hline Historical background & $\begin{array}{l}\text { Pre-existing geographic logic, as an industrial } \\
\text { district since the 19th century }\end{array}$ & Short history: regional cluster as of 2002 \\
\hline Industries & Traditional manufacturing industry (metal-working) & $\begin{array}{l}\text { Cultural industries (videogame, audiovisual and } \\
\text { image) }\end{array}$ \\
\hline Firms' knowledge focus & Exploitation & Exploration \\
\hline Governance board structure & $\begin{array}{l}\text { Three permanent employees and nine 'key players' } \\
\text { delegated by institutions }\end{array}$ & $\begin{array}{l}\text { Permanent team of seven employees and a } \\
\text { director }\end{array}$ \\
\hline $\begin{array}{l}\text { Main objective of the } \\
\text { governance structure in terms } \\
\text { of ambidexterity }\end{array}$ & $\begin{array}{l}\text { To help SMEs cope with changes by acquiring new } \\
\text { technology and knowledge and applying them in } \\
\text { products }\end{array}$ & $\begin{array}{l}\text { To help SMEs exploit generic knowledge to } \\
\text { support their growth } \\
\text { To increase knowledge flows and create } \\
\text { dialogue across industries }\end{array}$ \\
\hline $\begin{array}{l}\text { Governance structure's role } \\
\text { and priorities in terms of } \\
\text { knowledge management }\end{array}$ & $\begin{array}{l}\text { Identify external scientific and technological } \\
\text { knowledge for the engines (through R\&D projects) } \\
\text { Convert and disseminate external technological } \\
\text { knowledge for the majority of SMEs (through } \\
\text { collective actions/platforms) } \\
\text { Identify external organisational and managerial } \\
\text { knowledge for SMEs that have already acquired } \\
\text { some technological maturity (through collective } \\
\text { actions) }\end{array}$ & $\begin{array}{l}\text { Identify generic knowledge and create } \\
\text { opportunities for firms to meet through informal } \\
\text { meetings } \\
\text { Increase exploration within the cluster through } \\
\text { formal programmes and R\&D/non R\&D projects }\end{array}$ \\
\hline $\begin{array}{l}\text { Type of underlying knowledge } \\
\text { that must be produced to } \\
\text { reach this objective }\end{array}$ & $\begin{array}{l}\text { Exploration knowledge: external scientific and } \\
\text { technological knowledge } \\
\text { In a lesser way, exploitation knowledge: } \\
\text { organisational and managerial knowledge }\end{array}$ & $\begin{array}{l}\text { Exploitation knowledge: generic knowledge } \\
\text { In a lesser way, exploration knowledge: scientific } \\
\text { and technological knowledge }\end{array}$ \\
\hline $\begin{array}{l}\text { Type of cluster ambidexterity } \\
\text { and governance structure's } \\
\text { role }\end{array}$ & $\begin{array}{l}\text { Specialised model (exploration or exploitation) } \\
\text { Substituting for inter-cluster relations to provide } \\
\text { exploitation firms with exploration knowledge }\end{array}$ & $\begin{array}{l}\text { Dual model (exploration and exploitation) } \\
\text { Helping each firm become ambidextrous by } \\
\text { providing it with specific complementary } \\
\text { knowledge blocks (essentially in terms of } \\
\text { exploitation knowledge) }\end{array}$ \\
\hline $\begin{array}{l}\text { Performance of cluster } \\
\text { governance actions }\end{array}$ & $\begin{array}{l}\text { Helps engines improve their potential and realised } \\
\text { absorptive capacity } \\
\text { Persistence of obstacles to knowledge creation for } \\
\text { most SMEs in the absence of a common knowledge } \\
\text { base }\end{array}$ & $\begin{array}{l}\text { Creation of a common knowledge base that } \\
\text { makes the combination of potential and realised } \\
\text { absorptive capacity effective for most SMEs }\end{array}$ \\
\hline
\end{tabular}

cluster ambidextrous (through the specialised model) and providing exploitation firms with the exploration knowledge developed elsewhere, that is, through other cluster firms' R\&D collaborations.

We have about $10 \%$ of firms, mostly the largest ones that will engage in $R \& D$ programs and $20 \%$ that will by themselves engage into educational programs and actions and acquire new knowledge. However, we provide the other $70 \%$ with turnkey packages in order to implement directly within the SMEs the new knowledge. (managing director of the governance structure, September 2012)

By substituting itself for R\&D collaborations among the SMEs and implementing the results of exploration knowledge, the cluster governance structure actually enhanced not the firms' exploration knowledge but rather their exploitative abilities. Such actions reinforced firms' specialisation in exploitation. A synthesis of these results appears in Table 1.

\section{Imaginove}

Imaginove included 85 firms (as of 7 April 2012): 33 from the movie industry, 30 from the multimedia sector, 14 from the videogame industry and 8 others, mostly SMEs (88\%). It also included 9 research laboratories and 18 training centres/schools (Imaginove, 2013). Imaginove was created by three founders: Lyon Game (videogame association), Image Rhône-Alpes (audiovisual association) and CITIA (Cité de l'image en movement, City of the image in movement). Members operated in creative and digital content industries, such as video games, multimedia, audiovisual and images. The cluster reflected a regional policy implemented in 2002 by the Rhône-Alpes region to encourage a digital entertainment cluster. In July 2005, the Imaginove regional cluster was designated a competitiveness pole and expanded to include the image industry, to create further synergies. The main objective of its governance structure was to ensure that SMEs knew one another and help them work together. 
Innovation in SMEs requires managers who believe in it. It is a big investment. The point is to increase knowledge flows, to create a dialogue. This requires 'true' collaboration. (member of the governance structure, in charge of scientific valorisation, research centre and university professor, February 2009)

The situation differed radically from the one characterising Arve-Industries though, in that more SMEs participated in exploration activities in this fast moving industry. The number of R\&D projects for which the project leader was an SME or was affiliated with at least one SME during 2009-2011 was far higher for Imaginove than for ArveIndustries (84 vs 70\%; see Appendix D). Whereas most firms in Arve-Industries needed to move towards exploration, firms in Imaginove, 'by nature', were geared towards exploration activities. They thus needed to engage in more exploitation to absorb the necessary underlying knowledge (e.g., generic knowledge about human resources, marketing) to support their growth.

Actors in this governance structure actively sought to enhance both exploration and exploitation knowledge. For about $10 \%$ of firms that succeeded in integrating key commercial and economic knowledge into their business models, the governance structure also aimed to provide them with new knowledge on various subjects and to foster R\&D collaboration. At a more regional level, specific calls for projects - such as 'Serious Games and New Usages' encouraged firms to innovate and collaborate with local funding. Beyond formalised cooperation, several informal exchanges and actions were designed to exchange ideas or identify experts on specific themes (e.g., casual meetings around drinks, thematic conferences including creativity workshops, brainstorming sessions and innovation fairs). These informal meetings emerged progressively, in line with Imaginove's desire to encourage innovation projects and better define processes in the form of regular events or platforms for exchanging documents. They grew increasingly popular with member firms. Moreover, two larger projects aimed to increase exploration within the cluster: Media Valley, a generic project to set up a living lab, and Talent Factory, a large incubator that hoped to launch 10 projects annually across various industries (not necessarily R\&D projects).

To foster exploitation knowledge, two programmes helped members integrate basic common knowledge: Imaginove Commercial and Imaginove International, which helped various firms engage in commercial promotions or international activities (see Appendix D). Most firms were interested in gaining commercial, legal and managerial knowledge, as well as a more general understanding of the context of their industry and its economic model. Governance actions thus responded to immediate concerns. The cluster regarded itself as a provider of 'general' knowledge to member firms, which was clearly exploitative in nature.

Until now the priority has been to increase the turnover and expand commercial boundaries and, more generally speaking, to provide the underlying essential general knowledge to most of our very small cluster firms. (member of the governance structure, CITIA and University, June 2011)

However, by articulating existing knowledge and developing links among the three industries, even beyond the local region, the governance structure's efforts indirectly contributed to firms' integration of new knowledge too. A notable exploration domain therefore consisted of the absorption of existing knowledge from the other industries, which was especially useful for the creation of 'cross-media' products. Imaginove created relations between knowledge and competences, established spaces for transferring general knowledge and identified new business gateways.

In order to create opportunities for companies to meet, we link firms operating in the same activity and firms belonging to other industries (cross media). (member of the governance structure, CITIA, June 2011)

Overall then, the underlying objectives of Imaginove differed greatly from those of Arve-Industries. Approximately $10 \%$ of the members were engine firms who already had succeeded in integrating exploitation knowledge into their existing exploration activities. For these already ambidextrous firms, the governance structure basically helped them identify new possibilities and knowledge, especially through inter-organisational R\&D collaboration. For the other firms, which mainly were engaged in exploration (due to their industry), the governance structure helped them become ambidextrous by providing general knowledge in the form of various concrete, applied actions (related to employment and training, commercial and international development, management, property rights and so forth) and by creating new spaces for knowledge sharing.

Governance actions allow creating a link between cluster members, networks for knowledge sharing beyond the scope of their core business. (member of the governance structure, CITIA and University, September 2012)

We summarise the main findings from this case in Table 1.

\section{Discussion}

These two cases show that mere geographical proximity is not a sufficient condition to ensure knowledge processes and cluster ambidexterity for innovative firms. For SME clusters, the governance structure has a major role to play in organising efficient local interactions among players, as well as achieving ambidexterity at the cluster level. Prior research has validated the ambidexterity hypothesis for small firms (e.g., Lubatkin et al, 2006) but not addressed cluster ambidexterity or methods for managing underlying knowledge processes in clusters (Bocquet \& Mothe, 2010). With this empirical study, we attempt to investigate the role of governance structures for managing knowledge and cluster ambidexterity in two small firm clusters. The governance programmes and actions each cluster adopted were distinct, despite their common goal of reaching knowledge ambidexterity at the cluster level. 
In Arve-Industries, most SMEs focused on exploiting their advanced knowledge of precision mechanics, not the absorption of new knowledge, especially in microelectronics, even though exploration activities would have helped them evolve towards mechatronics. These small subcontractors have long-standing know-how and a deep industrial culture characterised by secrecy, low absorptive capacities and price-based competition. The task of the cluster governance structure was quite difficult, due to the high exploitation orientation of its members. Switching to an exploration and innovation culture would be difficult for most of them, and 'to facilitate the development of exploration capacity for intra-district firms in the search for greater information diversity, it is necessary to establish an organic structure that overcomes obstacles to experimentation and to the search for and analysis of new alternative sources' (Camison \& Villar-Lopez, 2012, p. 6). In this case, the cluster governance structure acted as an 'organic presence', combining structural flexibility with the productive flexibility offered by the former Technic Valley district while also strengthening engine firms' technological innovation capabilities. The initial focus was on engines that could improve the cluster's ability to scan the market for emerging technologies, absorb the technology acquired and perform complementary R\&D activities. The challenges of convincing the other SMEs to integrate external exploration knowledge required governance processes that could provide new technological knowledge directly to firms, as well as underlying processes that would allow the SMEs to absorb it.

The cluster ambidexterity model adopted by Arve-Industries thus focused on firm specialisation within the cluster, substituting for inter-firm collaboration - for the moment. In contrast with the intermediated network model proposed by Lee et al (2010), the primary role of governance is not to facilitate collaboration between SMEs. With their poor absorptive capacities, specialised SMEs cannot participate in a collaborative business model based on a horizontal structure, such that each firm focuses on the particular function in which it has a competitive advantage. Governance thus fills a crucial missing link between exploration and exploitation activities. By incorporating exploration into SMEs' operations, the governance structure contributes to enhance their realised absorptive capacities. Given that profits are created primarily through realised absorptive capacity (Grant, 1996), it also helps SMEs improve their performance. However, this performance remains fragile, because SMEs are highly dependent on the knowledge transfer implemented by the governance structure. Because the engines did not have collaborative relationships with other firms though, governance processes and the direct implication of governance structure members became vectors of knowledge dissemination through formal mechanisms (platforms and collective actions). The actors in charge of cluster governance sought to enhance realised absorptive capacity through greater formalisation of knowledge processes, especially in the utilisation phases. Their model relies essentially on a technology push, and they act as KEI (Hine et al, 2010).

We thus extend Spithoven et al's (2011) results by showing how governance can help SMEs use and transform new knowledge in their operations, providing them with modules that increase their realised absorptive capacities and industrial performance so that, in the future, some SMEs may enter into collaborations. Thus, its role is not limited to that of an intermediary (Howells, 2006). This characteristic may be linked to the composition of its governance structure. The members of the steering committee all come from local institutions active in the local development of the Arve valley (which is key to the regional economy). Thus, these members have dual roles, in representing their institution (e.g., professional association for subcontracting metal-cutting activities, economic development agency and centre for innovation in mechatronics) and taking their position in the cluster, and both roles are closely related.

At Imaginove, the situation is quite different. The young SMEs were active in creative, cultural and technological activities and oriented towards new ideas, innovation and exploration, largely as a result of the rapid evolution of their multimedia markets. They thus possessed potential absorptive capacity (Zahra \& George, 2002; Lazaric et al, 2008) and constantly sought the acquisition of new knowledge. Moreover, the Imaginove cluster was created with the explicit objective of linking three cultural industries, so member firms were inclined to explore knowledge that existed elsewhere that they might integrate or recombine. To foster this tendency towards exploration, the cluster pushed R\&D projects across industries, relying on engine firms that already possessed exploitation knowledge and already were ambidextrous. However, it also focused on helping small firms engage in exploitation activities by providing them with generic knowledge about markets, human resources and commercial and managerial aspects. Imaginove exhibited an input knowledge management strategy that appeared well adapted to the short-term needs of its members and contributed to the creation of a common knowledge base. Priority was given to knowledge intelligence and knowledge dissemination across the three industries.

By providing exploitative knowledge to member firms, Imaginove fostered the SMEs' absorptive capability and enabled them to recognise the value of external information, assimilate it and apply it to commercial ends (Cohen \& Levinthal, 1990). Indeed, firms that have the ability to acquire and assimilate knowledge without being able to transform and exploit it could not improve their performance. To reach this objective, the cluster governance established pre-requisite conditions to help each firm become ambidextrous. This is in line with Kauppila's (2007) dual model in which the cluster is ambidextrous due to firms' ambidexterity. From that perspective, Imaginove has a structural advantage over Arve-Industries, because it combines SMEs from different industries and is involved in fast-changing, young industries. Innovation 
intermediaries therefore not only provide immediate, 'one-off' intermediary services to their clients but also seek to offer longer term, 'relational' innovation capabilities (Howells, 2006).

The question of which model is better requires a contingency approach. As is true for most qualitative research, the response our study offers is that 'it depends'.

1. With regard to the role of the governance structure, the two models differ radically. In Arve-Industries, the governance structure acts as a substitute for inter-firm relations by incorporating results from $\mathrm{R} \& \mathrm{D}$ collaborations into SMEs' operations. In contrast, Imaginove's governance structure plays a more complementary role, creating an enabling environment for inter-firm relationships. By enhancing realised absorptive capacity, the impact of the actions implemented by Arve's governance structure on SMEs performance is more direct. But these 'pushy' actions can also make the firms more dependent, such that the performance of the specialised model on ambidexterity measures depends on the ability of SMEs to learn from governance actions and thus become able, in their turn, to engage in R\&D collaborations.

2. Stemming directly from the previous point, we might question whether the type of model is linked to the cluster's lifetime and history, or to a specific phase in the cluster's development. Rather paradoxically, ArveIndustries, which has a long history in the mechanical industry and the Technic Valley district, suffers from unfavourable preconditions for a collective cluster strategy and inter-organisational cooperation, due to negative agglomeration externalities (i.e., lack of qualified employees, proximity of Switzerland where wages are much higher, exacerbated competition, context of secrecy and distrust). We could argue that Arve-Industries is in its infancy, from a cluster logic, such that member firms are far from showing an adherence to the cluster's objectives and collective game. Imaginove member firms instead are collectively conscious of the interests of the cluster and of the gains they could obtain through the cluster and its collective strategy.

3. Such traits may be due to sectoral effects. The relatively young game and video industries show a convergence that prompts firms to open themselves to the other industries. The convergence between the very specialised traditional mechanical industry and the newer micro/nano electronic industry (as required for mechatronics) instead is much more delicate, involving firms with completely different technological levels, cultures and so forth.

\section{Conclusion}

Six years after the creation of these two clusters, their results appear encouraging in terms of the objective of reaching cluster ambidexterity. We have illustrated an intermediated model of cluster ambidexterity, in which a governance structure's actions in support of knowledge management differ, depending on the type of cluster ambidexterity being pursued. Efforts resulting from governance structures can create and sustain interactions, especially among small firms that cannot perceive and/or capture strategic opportunities. The pursuit of ambidexterity aims to provide exploitation knowledge to the (very) small creative firms that experience difficulties in their day-to-day operations (Imaginove), as well as to transfer exploration knowledge generated by R\&D projects and research to small industrial subcontracting firms to enhance their industrialisation processes (Arve-Industries).

These results clarify the intermediary role of governance structure for two types of ambidexterity in SME clusters. On the one hand, at Arve-Industries, SME cluster members specialise in exploitative knowledge, while the governance structure provides the missing exploratory knowledge. The governance structure acts as a third party (Spithoven et al, 2011), providing some exploratory knowledge that stems from inter-organisational R\&D cooperation, in a sort of intermediated specialised model. However, the specificity of the governance structure also lies in its direct implication in some programmes, because most of the SMEs are not (yet) capable of entering R\&D collaborations. It would be interesting to investigate more thoroughly the factors that explain this direct implication (or not) of the governance members (e.g., age of the cluster, members' characteristics, type of governance members that are not employed and paid by the cluster). On the other hand, at Imaginove, cluster governance helps all firms become more ambidextrous and facilitates collaborative relationships, leaving firms largely autonomous in their innovation activities, according to an intermediated dual model.

These findings also show that there is no 'best' cluster ambidexterity model. Governance structures must adapt their actions to the context in which the cluster emerges and to the firms' specific traits (Pilliana, 2008). They have some leeway for modifying the initial cluster characteristics though. To exert such significant actions and impact, cluster governance structures must already have the necessary human, material and financial resources to evaluate and fill deficits in member firms' resources. Furthermore, as mentioned previously, the performance of the two intermediated cluster models of ambidexterity is an important determinant of which model to pursue. Finally, the role of the governance structure, as a substitute or complement to the absorptive capacity of SME member firms, depends not only on the historical context of the cluster but also on its development stage, sector specificities and individual firm characteristics. Thus, there is no simple way to answer to the question about which model is best. The response stems from various external and internal dimensions. Considering the two studied cases, and in line with Kauppila (2007), we assert that Imaginove's dual model is likely to have longer lasting performance effects. Arve-Industries' specialised model may be a necessary first step to help the firms reach a minimum level of absorptive capacity that will enable them to benefit from inter-firm $\mathrm{R} \& \mathrm{D}$ collaborations. 
This study also features some limitations. First, the performance benefits of cluster membership and governance actions are difficult to evaluate on a quantitative basis. Although most firms can describe the benefits of cluster membership, a quantitative evaluation remains difficult. We cannot unequivocally establish direct causal effects between governance actions and improved innovative or general performance. This challenge is widely acknowledged among French competitiveness poles, which generally lack the personnel or resources to undertake such tracking. Second, we have identified governance actions at a particular stage (i.e., emergence and growth phases) of the clusters, but we lack a longitudinal history. It would be interesting to study the effects of the cluster lifecycle on knowledge management and cluster ambidexterity over time, because the constraints and performance factors may differ. Linking the cluster lifecycle to the industry lifecycle also might provide interesting insights, in the sense that knowledge management and ambidexterity aspects differ with each phase in the industry lifecycle: mature for ArveIndustries, emerging within Imaginove.

\section{References}

ALBERTI F (2001) The governance of industrial districts: a theoretical footing proposal. LIUC Papers 82, Serie Piccola e Media Impresa 5, January, [WWW document] http://www.biblio.liuc.it/liucpap/pdf/82.pdf (accessed 7 April 2012).

ANTONELLI C (2006) The business governance of localized knowledge: an information economics approach for the economics of knowledge. Industry and Innovation 13(3), 227-261.

ARIKAN AT (2009) Inter-firm knowledge exchanges and the knowledge creation capability of clusters. Academy of Management Review 34(4), 658-676.

ARVE-INDUSTRIES. (2012) Strategic Business Units. [WWW document] http://www.arve-industries.fr/coupe__usinage-fr906.html (accessed 7 April 2012).

BAHLMANN MD and HUYSMAN MH (2008) The emergence of a knowledgebased view of clusters and its implications for cluster governance. Information Society 24(5), 204-318.

Bathelt H, Malmberc A and Maskell P (2004) Clusters and knowledge: local buzz, global pipelines and the process of knowledge creation. Progress in Human Geography 28(1), 31-56.

BIERLY PE and DALY PS (2007) Alternative knowledge strategies, competitive environment, and organisational performance in small manufacturing firms. Entrepreneurship Theory and Practice 31(4), 493-516.

BOCQUET R and MOTHE C (2010) Knowledge governance within clusters: the case of small firms. Knowledge Management Research and Practice 8(3), 229-239.

BOSCHMA RA (2005) Proximity and innovation: a critical assessment. Regional Studies 39(1), 61-74.

CAMISON C and VILLAR-LOPEZ A (2012) On how firms located in an industrial district profit from knowledge spillovers: adoption of an organic structure and innovation capabilities. British Journal of Management 23(3), 361-382.

COHEN WM and LEVINTHAL DA (1990) Absorptive capacity: a new perspective on learning and innovation. Administrative Science Quarterly 35(1), $128-152$.

DATTA A (2011) Review and extension on ambidexterity: a theoretical model integrating networks and absorptive capacity. Journal of Management and Strategy 2(1), 2-22.

DUNCAN R. (1976) The ambidextrous organization: designing dual structures for innovation. In The Management of Organization (KILlMAN RH, PONDY LR and SLeVen D, Eds), pp 167-188, North Holland, New York.
These results have far-reaching managerial implications for firms engaged in cluster activities, as well as for institutional cluster governance actors and policymakers. We have identified two radically different modes of cluster governance that lead to ambidexterity at the cluster level, along with their preconditions. The process of cluster governance aims to enhance members' competitiveness and innovation performance, so small firms may be more inclined to belong to a cluster. Evaluations of cluster performance by innovation policymakers thus should include consideration of the actions taken through the governance structure, not only in terms of knowledge management and ambidexterity but also more generally to enhance member firms' common representations and involvement in collective actions and inter-firm collaborations. These actions are not entirely geared towards R\&D programmes and exploration but they also include various other acts that favour exploitation and non-technological innovations. Cluster innovation performance, as the notion of ambidexterity suggests, is based on these two forms of knowledge.

FERRARY M (2011) Specialised organisations and ambidextrous clusters in the open innovation paradigm. European Management Journal 29(3), 181-192.

GIBSON CB and BIRKINSHAW J (2004) The antecedents, consequences and mediating role of organizational ambidexterity. Academy of Management Journal 47(2), 209-226.

GILSING V (2000) Cluster governance: how clusters can adapt and renew over time. DRUID PhD-conference, January, pp 18-27, Copenhagen, Denmark, http://www.druid.dk/conferences/winter2000/gilsing.

GRANT R (1996) Prospering in dynamically-competitive environments: organizational capability as knowledge integration. Organization Science 7(4), 375-387.

GuPTA AK, SMITH KG and SHALLEY CE (2006) The interplay between exploration and exploitation. Academy of Management Journal 49(4), 693-706.

Hine DC, PARKer R and Ireland D (2010) The knowledge exchange intermediary as service provider: a discussion and an Australian case. The Service Industries Journal 30(5), 713-729.

HOWELLS J (2006) Intermediation and the role of intermediaries in innovation. Research Policy 35(5), 715-728.

IMAGINOVE. (2013) List of member firms. [WWW document] http://wwW .imaginove.fr/front/47-14-1-Annuaire-public-des-adherents.

INKINEN T and SUORSA K (2010) Intermediaries in regional innovation systems: high-technology enterprise survey from northern Finland. European Planning Studies 18(2), 169-187.

JONES C, HESTERLY WS and BORGATTI SP (1997) A general theory of network governance: exchange conditions and social mechanisms. Academy of Management Review 22(4), 911-945.

KAUPPILA OP (2007) Towards a network model of ambidexterity. Working Paper 429, Helsinki School of Economics, May. Paper presented at the 17 th Nordic Workshop on Interorganisational Research, 16-18 August.

KRAAIJENBRINK J and WIJNHOVEN F (2008) Managing heterogeneous knowledge: a theory of external knowledge integration. Knowledge Management Research \& Practice 6(4), 274-286.

LAZARIC N, LONGHI C and THOMAS C (2008) Gatekeepers of knowledge versus platforms of knowledge: from potential to realized absorptive capacity. Regional Studies 42(6), 837-852.

LeE S, PARK G, YOON B and PARK J (2010) Open innovation in SMEs - an intermediated network model. Research Policy 39(2), 290-300.

LIN Z, YANG $\mathrm{H}$ and DEMIRKAN I (2007) The performance consequences of ambidexterity in strategic alliance formations: empirical 
investigation and computational theorizing. Management Science 53(10), 1645-1658.

LUBATKIN MK, SINSEK Z, LINZ Y and VEIGA JF (2006) Ambidexterity and performance in small- to medium-sized firms: the pivotal role of top management team behavioral integration. Journal of Management 32(5), 646-672.

LYNN LH, REDDY NM and ARAM ID (1996) Linking technology and institutions: the innovation community framework. Research Policy 25(1), 91-106.

MALMBERG A and MASKELL P (1997) Towards an explanation of regional specialization and industry agglomeration. European Planning Studies 5(1), 25-41.

MALMBERG A and MASKell P (2002) The elusive concept of localization economies: towards a knowledge-based theory of spatial clustering. Environment and Planning 34(3), 429-449.

MARCH JG (1991) Exploration and exploitation in organisational learning. Organization Science 2(1), 71-87.

MARShall A (1920) Principles of Economics. Palgrave Macmillan, London.

MARTIN-DE-CASTRO G, LOPEZ-SAEZ P and NAVAS-LOPEZ JE (2008) Processes of knowledge creation in knowledge-intensive firms: empirical evidence from Boston's Route 128 and Spain. Technovation 28(4), 222-230.

MASKELL P (2001) Towards a knowledge-based theory of the geographical cluster. Industrial and Corporate Change 10(4), 921-943.

Miles MB and HUBERMAN AM (1984) Qualitative Data Analysis. Sage, Newbury Park, CA

MiLES MB and HUBERMAN AM (1994) Qualitative Data Analysis, 2nd edn, Sage, Newbury Park, CA.

NONAKA I (1994) A dynamic theory of organisational knowledge creation. Organization Science 5(1), 14-37.

NONAKA I and TAKEUCHI H (1995) The Knowledge-Creating Company. Oxford University Press, New York.

NONAKA I, VON KROGH G and VOELPEL S (2006) Organisational knowledge creation theory, evolutionary paths and future advances. Organization Studies 27(8), 1179-1208.
O'ReIlly CA and TushmAN ML (2004) The ambidextrous organisation. Harvard Business Review 82(4), 74-81.

OSHRI I, PAN SL and NEWELL S (2005) Trade-offs between knowledge exploitation and exploration activities. Knowledge Management Research \& Practice 3(1), 10-24.

PILLANIA R (2008) Creation and categorization of knowledge in automotive components SMEs in India. Management Decision 46(10), 1452-1463.

PONDS R, VAN OORT F and FRENKEN K (2007) The geographical and institutional proximity of research collaboration. Papers in Regional Science 86(3), 423-443.

PORTER ME (1998) Clusters and the new economics of competition. Harvard Business Review 76(6), 77-90.

ROTHAERMEL FT and DEEDS DL (2004) Exploration and exploitation alliances in biotechnology: a system of new product development. Strategic Management Journal 25(3), 201-221.

SAMMARRA A and BIGGIERO L (2008) Heterogeneity and specificity of interfirm knowledge flows in innovation networks. Journal of Management Studies 45(4), 800-829.

SPithoven A, CLARYSSE B and KNOCKAert M (2011) Building absorptive capacity to organise inbound open innovation in traditional industries. Technovation 31(1), 10-21.

TORRE A and Rallet A (2005) Proximity and localization. Regional Studies 39(1), 37-59.

TUSHMAN ML and O'ReILly CA (1996) Ambidextrous organizations: managing evolutionary and revolutionary change. California Management Review 38(4), 8-30.

WAXELL A (2009) Guilty by association: a crossindustrial approach to sourcing complementary knowledge in the Uppsala biotechnology cluster. European Planning Studies 17(11), 1605-1624.

ZACK MH (2003) Rethinking the knowledge-based organization. Sloan Management Review 44(4), 67-71.

ZAHRA S and GEORGE G (2002) Absorptive capacity: a review, reconceptualization and extension. Academy of Management Review 27(2), 185-203. 


\section{Appendix A}

Table A1 Composition of the two governance structures

\begin{tabular}{lll}
\hline & Strategic level & Operational level \\
\hline $\begin{array}{ll}\text { Arve- } \\
\text { Industries }\end{array}$ & $\begin{array}{l}\text { The strategy is defined by the Executive Board (17 members), } \\
\text { approved by the Administration Council (60 members) and } \\
\text { endorsed by the General Assembly }\end{array}$ & $\begin{array}{l}\text { Programmes and actions are implemented and coordinated by a } \\
\text { steering committee (CODIR) composed of } 10 \text { members. This } \\
\text { committee also has a role of reporting to the Executive Board } \\
\text { Composition of the steering committee: } \\
\text { Director }\end{array}$ \\
$\begin{array}{ll}\text { Vice Director (CTDEC) } \\
\text { Local general council, Thésame, CTDEC, University of Savoie, } \\
\text { Chamber of Commerce and Economic Development Agency }\end{array}$ \\
$\begin{array}{ll}\text { Imaginove } \\
\text { The strategy is defined by the Executive board (three members) } \\
\text { approved by the Administration Council (nine members) and } \\
\text { endorsed by the General Assembly }\end{array}$ & $\begin{array}{l}\text { Programmes and actions are implemented and coordinated by a } \\
\text { permanent team including seven full-time employees. } \\
\text { This team also has a role of reporting to the executive board }\end{array}$ \\
\hline
\end{tabular}

Notes: CTDEC is the French national centre for metal-working subcontracting.

\section{Appendix B}

\section{Interview guide structure and data triangulation}

\section{Emergence and history of the cluster}

Interview data triangulated with articles in newspapers and academic journals on Technic Valley and with websites on industrial districts.

1. Context of emergence

2. Pre-conditions, description of industrial structure and firms' characteristics

3. Pre-existence of inter-organisational collaborations

\section{Structure of the cluster}

Interview data triangulated with articles in academic journals and with the website of the French government pertaining to clusters.

4. Evolution of firms' characteristics since 2005

5. Evolution of relational modes and collaboration since 2005

6. Evolution of firms' performance (innovation) since 2005

\section{Characteristics of the governance structure}

Interview data triangulated with articles in conferences, with the websites of the French government pertaining to clusters and with the websites of the two clusters

7. Composition of governance structure and membership

8. Description of strategic and operational governance
9. Main roles devoted to governance

10. Main direct and indirect implication

\section{Main objectives of governance}

11. Interest of governance in knowledge management.

12. If yes: types of knowledge and what type of management.

13. Types of innovation within the cluster.

14. Implication of governance to foster innovation.

15. If yes: how and for what kind of innovation?

\section{Typology of developed projects/actions to reach such objectives}

Interview data triangulated with articles in conferences, with the websites of the French government pertaining to clusters, and with the websites of the two clusters

16. Description of projects, programmes and actions developed by governance

17. Type of implication by governance members (initiator, financing, pilot, control, follow-up, intermediary, etc.)

\section{Results of these projects/actions}

18. Main indicators of inputs and outputs at the cluster level? At the firm level?

19. Causal relationship between governance implication and results 


\section{Appendix C}

Table C1 Extract from the coding grid for the item exploration/exploitation

\begin{tabular}{|c|c|c|c|c|c|c|}
\hline Cluster & $\begin{array}{l}\text { Person } \\
\text { interviewed }\end{array}$ & Verbatim & $\begin{array}{l}\text { Type of } \\
\text { knowledge } \\
\text { circulation }\end{array}$ & Objective for cluster firms & $\begin{array}{l}\text { Type of cluster } \\
\text { ambidexterity }\end{array}$ & $\begin{array}{l}\text { Performance in terms of } \\
\text { innovation }\end{array}$ \\
\hline $\begin{array}{l}\text { Arve- } \\
\text { Industries }\end{array}$ & $\begin{array}{l}\text { Governance } \\
\text { director }\end{array}$ & $\begin{array}{l}\text { 'The digital platform is an efficient tool for the firms that are } \\
\text { engaged in } R \& D \text { projects. They have access codes and } \\
\text { specific rights that allow them to share new technological } \\
\text { knowledge while ensuring confidentiality. Beyond R\&D } \\
\text { projects, I do not believe in the usage of such a platform, } \\
\text { especially for SMEs. Most of them do not have a strategic } \\
\text { vision. Their horizon do not exceed one month!' (February } \\
2009 \text { ) }\end{array}$ & $\begin{array}{l}\text { Exploration for } \\
\text { engines, } \\
\text { exploitation for } \\
\text { most SMEs }\end{array}$ & $\begin{array}{l}\text { Governance provides engines } \\
\text { with external scientific and } \\
\text { technological knowledge } \\
\text { through R\&D projects }\end{array}$ & $\begin{array}{l}\text { Specialisation } \\
\text { in exploration } \\
\text { or exploitation }\end{array}$ & $\begin{array}{l}\text { Governance complements the } \\
\text { R\&D activities of engines and } \\
\text { substitutes for R\&D by most } \\
\text { SMEs }\end{array}$ \\
\hline Imaginove & $\begin{array}{l}\text { Governance } \\
\text { director }\end{array}$ & $\begin{array}{l}\text { 'Governance favours knowledge sharing about markets, } \\
\text { human resources, commercial and managerial aspects etc., } \\
\text { and contributes to put into relation non technological } \\
\text { competencies between the three industries. In fact, it } \\
\text { identifies the gateways between industries that are } \\
\text { necessary for innovation'. (March 2009) }\end{array}$ & $\begin{array}{l}\text { Exploitation (for } \\
\text { exploratory } \\
\text { firms) }\end{array}$ & $\begin{array}{l}\text { Identify generic knowledge and } \\
\text { create a link between the three } \\
\text { industries }\end{array}$ & $\begin{array}{l}\text { Ambidextrous } \\
\text { firms }\end{array}$ & $\begin{array}{l}\text { Creation of a common } \\
\text { knowledge base that is } \\
\text { necessary for innovation }\end{array}$ \\
\hline
\end{tabular}

\section{Appendix D}

Table D1 Descriptive statistics for the two clusters

\begin{tabular}{|c|c|c|c|c|c|c|c|c|}
\hline & \multicolumn{4}{|c|}{ Arve-Industries } & \multicolumn{4}{|c|}{ Imaginove } \\
\hline & 2009 & 2010 & 2011 & Mean & 2009 & 2010 & 2011 & Mean \\
\hline Number of R\&D labelled projects & 16 & 9 & 25 & 17 & 27 & 35 & 51 & 38 \\
\hline For which the project leader is an SME & $6(38 \%)$ & $1(11 \%)$ & $6(24 \%)$ & $4(24 \%)$ & $18(67 \%)$ & $22(63 \%)$ & $41(80 \%)$ & $27(70 \%)$ \\
\hline With at least one SME & $12(75 \%)$ & $5(56 \%)$ & $9(36 \%)$ & $9(57 \%)$ & $24(89 \%)$ & $23(66 \%)$ & $50(98 \%)$ & $32(84 \%)$ \\
\hline Number of R\&D projects (ongoing research but unfinished project at the end of 2009 or 2010) & 21 & 22 & 30 & 24 & 31 & 22 & 28 & 27 \\
\hline Projects aiming at elaborating a product or process & $N A^{a}$ & 6 & 6 & $N C^{b}$ & 28 & 12 & 20 & 20 \\
\hline Number of finished R\&D projects (since the creation of the cluster in 2006 ) & 8 & 11 & 16 & 12 & 5 & 11 & 15 & 10 \\
\hline Number of patents stemming from labelled projects & 10 & 6 & 2 & 6 & 4 & NA & NA & NC \\
\hline Other intellectual property rights (models and designs) & 19 & 5 & 7 & 10 & 2 & NA & NA & NC \\
\hline Number of scientific articles published & 14 & 12 & 16 & 14 & 4 & NA & NA & NC \\
\hline Number of international scientific communications & 16 & 1 & 8 & 8 & 2 & NA & NA & NC \\
\hline Number of education programmes settled up following a demand by the cluster & 31 & 10 & 10 & 17 & 19 & 10 & 13 & 14 \\
\hline Number of firms helped by the cluster in a commercial promotion or international partnership activity & 65 & 25 & 35 & 42 & 25 & 124 & 91 & 80 \\
\hline Rate of export by firms (in percentage) & 48 & 42 & 38 & 43 & $<1$ & 4 & 10 & 5 \\
\hline Proportion of SME realising more than $5 \%$ of their turnover outside of France (in percentage) & 44 & 60 & 63 & 56 & 1 & 24 & 26 & 17 \\
\hline
\end{tabular}

Source: http://competitivite.gouv.fr/.

${ }^{a}$ Not available.

${ }^{\mathrm{b}}$ Not computed. 


\section{About the Authors}

Rachel Bocquet is full professor of strategic and innovation management at the University of Savoie, France. Her research deals with the determinants and the complementarity of organizational and technological innovations. She is also currently investigating the effects of cluster membership on small and medium-sized firms' innovation performance. She has published several articles in books and international journals.
Caroline Mothe is full professor of strategic and innovation management at the University of Savoie, France, where she mainly teaches strategy and innovation management. Interested in inter-firm cooperation and in innovative organizations, she actually coordinates several research projects on intra- and inter-organizational innovation processes. She has published many articles related to these fields in international journals. 